\title{
SOLVOLYSIS KINETIC STUDY AND DIRECT SPECTROFLUORIMETRIC ANALYSIS OF THE FUNGICIDE BENOMYL IN NATURAL WATERS*
}

\author{
Diène Diégane Thiaré ${ }^{1}$, Abdourakhmane Khonté ${ }^{1}$, Diégane Sarr ${ }^{1}$, Cheikh Diop ${ }^{2}$, \\ Mame Diabou Gaye-Seye ${ }^{1}$, Atanasse Coly ${ }^{*}$, François Delattre ${ }^{3}$, Alphonse Tine ${ }^{1}$, Jean-Jacques Aaron ${ }^{4 *}$ \\ ${ }^{1}$ Laboratoire de Photochimie et d'Analyse (LPA), Faculté des Sciences et Techniques, \\ Université Cheikh Anta Diop, Dakar, Sénégal \\ ${ }^{2}$ Institut des Sciences de l'Environnement (ISE), Faculté des Sciences et Techniques, \\ Université Cheikh Anta Diop, Dakar, Sénégal \\ ${ }^{3}$ Unité de Chimie Environnementale et Interactions sur le Vivant (UCEIV), ULCO, \\ BP 59140, Dunkerque, France \\ ${ }^{4}$ Laboratoire Géomatériaux et Environnement (LGE), EA 4508, \\ Université Paris-Est Marne-la-Vallée, 5 Boulevard Descartes, 77454 Marne-La-Vallée, France \\ *atcoly@ucad.sn; jeanjacquesaaron@yahoo.fr
}

A direct spectrofluorimetric method for the quantitative analysis of benomyl in natural waters is described here. Benomyl is an unstable, fluorescent fungicide that mainly decomposes into carbendazim and $n$-butyl-isocyanate in organic and aqueous solutions. The kinetics of benomyl solvolysis reactions were investigated in organic solvents (methanol and acetonitrile) and in aqueous solvent systems, including $\beta$-cyclodextrin $(\beta-\mathrm{CD})$, sodium dodecyl sulphate (SDS), dodecyltrimethylammonium chloride (DTAC), cetyltrimethylammonium chloride (CTAC), cetyltrimethylammonium hydroxide (CTAOH), Brij-700, Triton X-100 and water, at different $\mathrm{pH}$ and/or $\mathrm{NaOH}$ concentrations. The benomyl fluorescence signal was found to be quasi-completely stable in $10^{-2} \mathrm{M} \mathrm{NaOH}$ aqueous solution, various alkaline $\left(10^{-2} \mathrm{M} \mathrm{NaOH}\right)$ organised media, $\beta-\mathrm{CD}$ neutral solution and Triton $\mathrm{X}-100$ aqueous solutions of different $\mathrm{pH}$. Based on these results, a direct spectrofluorimetric analytical method was developed for the determination of benomyl in $10^{-2} \mathrm{M} \mathrm{NaOH}$ aqueous solution and Triton $\mathrm{X}-100$ solutions ( $\mathrm{pH} 7$ and $10^{-2} \mathrm{M}$ $\mathrm{NaOH}$ ), with wide linear dynamic range (LDR) values of two to three orders of magnitude, very low limit of detection (LOD) and limit of quantification (LOQ) values of $0.002-0.5 \mathrm{ng} / \mathrm{ml}$ and $0.007-2.0 \mathrm{ng} / \mathrm{ml}, \mathrm{re}-$ spectively, and small relative standard deviation (RSD) values of $0.2-1.7 \%$, according to the medium. This direct spectrofluorimetric method was applied to the evaluation of benomyl residues in natural waters, with satisfactory recovery values recorded (87-94\%).

Keywords: benomyl; solvolysis kinetics; solvent effects; direct fluorescence analytical method; water analysis.

\section{КИНЕТИЧКО ИСПИТУВАЊЕ НА СОЛВОЛИЗАТА И ДИРЕКТНА СПЕКТРОФЛУОРОМЕТРИСКА АНАЛИЗА НА ФУНГИЦИДОТ БЕНОМИЛ ВО ПРИРОДНИ ВОДИ}

Опишан е директен спектрофлуорометриски метод за квантитативна анализа на беномил во природни води. Беномилот е нестабилен, флуоресцентен фунгицид што во органски и водни раствори главно се разложува на карбендазим и $n$-бутилизоцијанат. Кинетиката на реакциите на солволиза беше испитувана во органски растворувачи (метанол и ацетонитрил) и во водни системи, вклучувајќ $\beta$-циклодекстрин $(\beta-\mathrm{CD})$, натриумдодецилсулфат $(\mathrm{SDS})$, додецил-

\footnotetext{
${ }^{*}$ This work was presented in part at the $\mathrm{XV}^{\text {th }}$ ISLS 2012 (International Symposium on Luminescence
} Spectrometry - Abstract 47) in Barcelona (Spain), 19-22 June 2012. 
триметиламониум-хидроксид (DTAC), цетилтриметиламониум-хлорид (CTAC), цетилтриметиламониум-хидроксид (СТАОН), Brij-700, Triton X-100 и вода на различни $\mathrm{pH}$ и/или концентрации на $\mathrm{NaOH}$. Беше утврдено дека флуоресцентниот сигнал на беномилот е целосно квазистабилен во воден раствор на $10^{-2} \mathrm{M} \mathrm{NaOH}$, разни други алкални медиуми $\left(10^{-2} \mathrm{M} \mathrm{NaOH}\right)$, нетурален раствор на $\beta$-CD и водни раствори на Triton X-100 при разни $\mathrm{pH}$. Врз основа на овие резултати е развиен директен спектрофлуорометриски аналитички метод за определување на беномил во водни раствори од $10^{-2} \mathrm{M} \mathrm{NaOH}$ и на Triton $\mathrm{X}-100\left(\mathrm{pH}=7\right.$ и $\left.10^{-2} \mathrm{M} \mathrm{NaOH}\right)$, со широк линеарен динамички опсег (LDR) со вредности од неколку реда на големина, многу ниски граници на детекција (LOD) и граници на квантификација (LOQ) од $0,002-0,5 \mathrm{ng} / \mathrm{ml}$ и $0,007-2,0 \mathrm{ng} / \mathrm{ml}$ и мали релативни стандардни девијации (RSD) од $0,2-1,7 \%$, во зависност од медиумот. Овој директен спектрофлуорометриски метод беше применет за определување на остатоци на беномил во природни води со задоволителни аналитички приноси (87-94\%).

Клучни зборови: беномил; кинетика на солволиза; ефект на растворувач; директен флуоресцентен аналитички метод; анализа на вода

\section{INTRODUCTION}

Throughout the world, a great variety of pesticides are applied to both rural and urban zones in order to control and eradicate pests. In Senegal, most of the sprayed anti-parasitic compounds are widely utilised in a large and longitudinal peri-urban agricultural area called the "Niayes area", where cultures are practiced during all seasons, and where most fruits and vegetables consumed in Dakar are harvested. Because of the number of pesticides used in the Niayes area and their persistence, serious problems related to chemical pollution and natural water contamination considerably affect its aquatic ecosystem. As a consequence, the development of rapid, sensitive, selective and precise analytical methods that are able to determine the level of pesticide residues present in the environment is necessary.

Benomyl is a benzimidazole carbamate fungicide introduced by DuPont Company in 1968, which is selectively toxic to micro-organisms and invertebrates, particularly earthworms. Because of the occurrence of cases of birth defects, possibly related to this fungicide, and of the worldwide prevalence of resistance of parasitic fungi to benomyl, its production by DuPont ceased in 2001 . Nevertheless, benomyl is still produced by other manufacturers, and remains in use in several countries, such as Senegal, where it is applied in the Niayes area. Generally, benomyl is utilised against a range of fungal diseases of full field crops and fruits [1-7]. For example, it is used to destroy some parasites, such as curvularia lunata, which attack rice grains [7]. Moreover, benomyl has the particularity to be unstable, and to solvolyse in organic or aqueous solutions, mainly yielding carbendazim, a relatively stable, fluorescent compound, which is also considered a fungicide, and $n$ butyl isocyanate [1, 3-6].
Due to this instability, the direct analysis of benomyl in solution is difficult to realise, and, most papers describe indirect analytical methods based on the carbendazim determination, although the analyte is often referred to as benomyl [2, 3, 811]. For example, a simple, indirect spectrofluorimetric method was reported for the determination of benomyl in grapes, in which benomyl was rapidly solvolysed in organic solvents to give the highly fluorescent metabolite carbendazim [2]. Benomyl was also determined by an indirect method, based on dispersive liquid-liquid microextraction (DLLME) of benomyl from acidified water sample solutions and conversion into carbendazim via solvolysis reactions, using dimethyl formamide (DMF) as an organic solvent, followed by liquid chromatography (LC) with fluorimetric detection [10]. In another indirect method, sample preparation involved supercritical fluid extraction with carbon dioxide, and further analysis of benomyl and other pesticides was performed without any additional clean-up step either by gas chromatography-mass spectrometry (GC-MS), after conversion into carbendazim and subsequent derivatisation with pentafluorobenzyl bromide (PFB$\mathrm{Br}) / \mathrm{K}_{2} \mathrm{CO}_{3}$, or by $\mathrm{LC}$ with diode array detection (LC-DAD), without derivatisation [11]. In addition, some papers have also presented several analytical methods for benomyl analysis in solution, without taking into account its possible solvolysis [12-15]. Nevertheless, there have been several analytical studies of benomyl, which attempted to stabilise the fungicide concentration before performing analysis [16-19]. One of these methods was solid-phase spectrofluorimetry (SPF), in which the relative fluorescence intensity of benomyl fixed on $\mathrm{C}_{18}$ silica gel was directly measured after drying and packing the gel beads in a 1-mm silica cell, by means of a solid phase attachment, leading to the low limit of detection (LOD) of $0.04 \mathrm{ng} \mathrm{ml}^{-1}$ [16]. 
Furthermore, synchronous SPF was applied to the simultaneous determination of benomyl and morestan residues in waters, with LOD values of 0.15 and $0.18 \mathrm{ng} \cdot \mathrm{ml}^{-1}$, respectively [17], and a spectrofluorimetric flow injection method was proposed for the resolution of binary mixtures of two fungicides, namely benomyl and thiabendazole, in waters and commercial formulations, with LOD values of 3.6 and $0.06 \mathrm{ng} \mathrm{ml}^{-1}$, respectively [18]. Using another spectrofluorimetric method, performed in acidic aqueous solution at $\mathrm{pH}=1.0$ and $25^{\circ} \mathrm{C}$, benomyl was stabilised and its fluorescence intensity was increased in the presence of $p$-sulfonatocalix[6]arene and of modified cyclodextrins (CDs), the best LOD value of $17.4 \mathrm{ng} \mathrm{ml}^{-1}$ being obtained with hydroxypropyl- $\beta-\mathrm{CD}[19]$.

On the basis of these observations, we have developed in this work a simple, direct spectrofluorimetric method (i.e. without degradation) for determining benomyl in liquid solution, after a preliminary kinetic study by fluorescence of its solvolysis reaction. For the first time, the benomyl degradation reaction kinetics were investigated by fluorescence, and compared in several media, namely organic solvents (acetonitrile and methanol), aqueous solutions of different $\mathrm{pH}$, and organised media, including aqueous micelles with various surfactants and $\beta-C D$ solution. One of the aims of the kinetic study was to evaluate the solvent conditions in which benomyl was quasi-stable, allowing its direct determination. Afterwards, we established a direct spectrofluorimetric method for the benomyl determination under optimal stability conditions, and applied this analytical method for the evaluation of benomyl residues in spiked natural waters collected in the Niayes area.

\section{EXPERIMENTAL}

\subsection{Reagents}

Analytical-reagent grade benomyl (98\% $\mathrm{m} / \mathrm{m})$ and carbendazim $(98 \% \mathrm{~m} / \mathrm{m})$ were purchased from Cluzeau Info Labo (Sainte-Foy-la-Grande, France). Sodium hydroxide pellets $(97 \% \mathrm{~m} / \mathrm{m})$ and spectroscopic-grade solvents, including acetonitrile, methanol, and chloroform, were obtained from Sigma Aldrich (Taufkirchen, Germany). Dodecyltrimethylammonium chloride (DTAC, 99\% $\mathrm{m} / \mathrm{m}$ ), cetyltrimethylammonium chloride (CTAC, $25 \%$ wt. solution in water, $d=0.968$ ), cetyltrimethylammonium hydroxide $(\mathrm{CTAOH}, 10 \%$ wt. solution in water, $d=0.988$ ), sodium dodecyl sulphate (SDS, $98 \% \mathrm{~m} / \mathrm{m})$, Brij-700 pellets $(99 \%$ $\mathrm{m} / \mathrm{m}, n=100)$, Triton X-100 (10\% wt. solution in water, $d=1.01)$ and $\beta$-cyclodextrin $(\beta$-CD 98\% $\mathrm{m} / \mathrm{m}$ ) were also received from Sigma Aldrich. Borate buffer solutions of different $\mathrm{pH}$ values $(4,7$ and 10) were purchased from Cluzeau Info Labo. Distilled water was used for preparing aqueous solutions of surfactants and $\beta-\mathrm{CD}$.

\subsection{Apparatus}

All spectral measurements were performed at room temperature with a Perkin-Elmer, Model LS-55 spectrophotofluorimeter interfaced with a microcomputer and processed by a software FLWinLab. Standard quartz fluorescence cuvettes with a 1-cm path length (Labo Moderne, France) were used for measurements, and a Pipetman 20$1000 \mu 1$ micropipette (Gilson, France) was used for dilutions. All analytical measurements were carried out under the same conditions of spectrophotofluorimeter sensitivity (slits width $=10 \mathrm{~nm} / 10 \mathrm{~nm}$, excitation/emission). The $\mathrm{pH}$ measurements were performed with a Consort pH-meter Model P107.

\subsection{Procedures}

\subsubsection{Solution preparation}

Stock solutions of surfactants (SDS, DTAC, CTAC, CTAOH, Brij-700, Triton X-100 $=0.02$ $\mathrm{mol} / \mathrm{L})$, cyclodextrin $(\beta-\mathrm{CD}=0.01 \mathrm{~mol} / \mathrm{L})$ and $\mathrm{NaOH}(1.0 \mathrm{~mol} / \mathrm{L})$ were prepared in $50-\mathrm{ml}$ volumetric flasks with distilled water, and used for serial dilutions. These solutions were protected against light with aluminium foil and could be stored in a refrigerator at $6^{\circ} \mathrm{C}$ for further use. On the contrary, benomyl working solutions were freshly prepared in the solvent under use and analysed immediately after preparation, in order to minimise possible fungicide decomposition. For the benomyl borate buffer solutions, the fungicide solubility was achieved by a 2 -min ultrasonic stirring.

\subsubsection{Analytical measurements}

An aliquot of fungicide working solution was placed in a quartz cuvette, and the fluorescence spectra were recorded at a scanning speed of 500 $\mathrm{nm} / \mathrm{min}$. Fluorescence intensity was monitored at fixed analytical excitation $\left(\lambda_{\mathrm{ex}}\right)$ and emission $\left(\lambda_{\mathrm{em}}\right)$ maximum wavelengths of the fungicide by measuring the spectra height signal. All fluorescence measurements were corrected for the solvent (background) signal with the appropriate blank. The kinetics of benomyl solvolysis reactions were studied in the various media under study by recording the variation of fluorescence intensity vs. time at the fungicide maximum emission wavelength. 


\subsubsection{Preparation of spiked natural water samples}

Water samples were collected in 1.51 amber glass bottles from natural waters (well, river, sea, draining waters), located inside and on the limits of the agricultural Niayes area. All samples were filtered through a quartz filter in order to remove any suspended organic matter. $10 \mathrm{ml}$ volumes of natural water samples were spiked in flasks with a known amount of fungicide, allowing a final concentration to be obtained within the calibration curve linear dynamic range (LDR). Afterwards, 0.1 $\mathrm{ml}$ of $1 \mathrm{M} \mathrm{NaOH}$ solution was added, and then each spiked natural water sample was introduced in a $250 \mathrm{ml}$ separator funnel with $10 \mathrm{ml}$ of chloroform. After $5 \mathrm{~min}$ of vigorous shaking, the organic phase was collected in a $100 \mathrm{ml}$ beaker while the aqueous layer was used for a second extraction. After a third extraction, the combined organic extracts were gently evaporated to dryness in a bath at $40^{\circ} \mathrm{C}$. The dry residue was then dissolved in a $10 \mathrm{ml}$ volume of analytical medium, and used for the fluorescence measurements.

\section{RESULTS AND DISCUSSION}

Firstly, we investigated by fluorescence the kinetics of benomyl solvolysis reaction in several media (organic solvents, aqueous solutions of different $\mathrm{pH}$, aqueous micelles and $\beta$-CD solutions); secondly, we developed and optimised a valid quantitative analytical procedure for the direct spectrofluorimetric determination of benomyl.

\subsection{Study of the benomyl solvolysis reaction kinetics}

Benomyl is very weakly soluble in water (solubility $=3.6 \mathrm{mg} / \mathrm{l}$ at $\mathrm{pH} 5$ and $25^{\circ} \mathrm{C}$ ) [4], stable under normal solid conditions of storage, but decomposes into carbendazim in solution. Consequently, as already indicated, benomyl solutions were always freshly prepared in the media under study. Preliminary tests showed that the fungicide was strongly fluorescent in all of the studied media, including methanol, acetonitrile, aqueous solutions of different $\mathrm{pH}, \beta-\mathrm{CD}$, SDS, DTAC, CTAC, CTAOH, Brij-700 and Triton X-100. In most media, the fluorescence signal was found to significantly increase or, in some cases, decrease with time, according to the medium (Figs. 1-3). The fluorescence signal evolution was attributed to the benomyl degradation into reaction products, mostly carbendazim and $n$-butylisocyanate $[4,5]$. Due to this particular behaviour, we decided to investigate the benomyl solvolysis kinetics in these different media and evaluate the conditions (solvent and $\mathrm{pH}$ ) in which the observed fluorescence signal would remain practically constant.

\subsubsection{Organic solutions}

In the case of benomyl acetonitrile and methanol solutions, the fluorescence intensity $\left(I_{\mathrm{F}}\right)$ significantly increased with time, and then attained a plateau region within approximately $100 \mathrm{~min}$ for both solvents (Fig. 1). However, in the plateau region, a continuous, rather weak and slow $I_{\mathrm{F}}$ increase was observed even after 24 hours. The existence of a plateau region in these kinetic curves indicated that the benomyl solvolysis reaction in organic media was not total, but led to equilibrium between benomyl and its degradation product(s) [5]. Analogous kinetic curves, apparently following a first-order kinetic law and recorded by means of a HPLC-DAD method, were also reported by Anastassiades and Schwack [11] for the conversion of benomyl into carbendazim in acetonitrile solution.

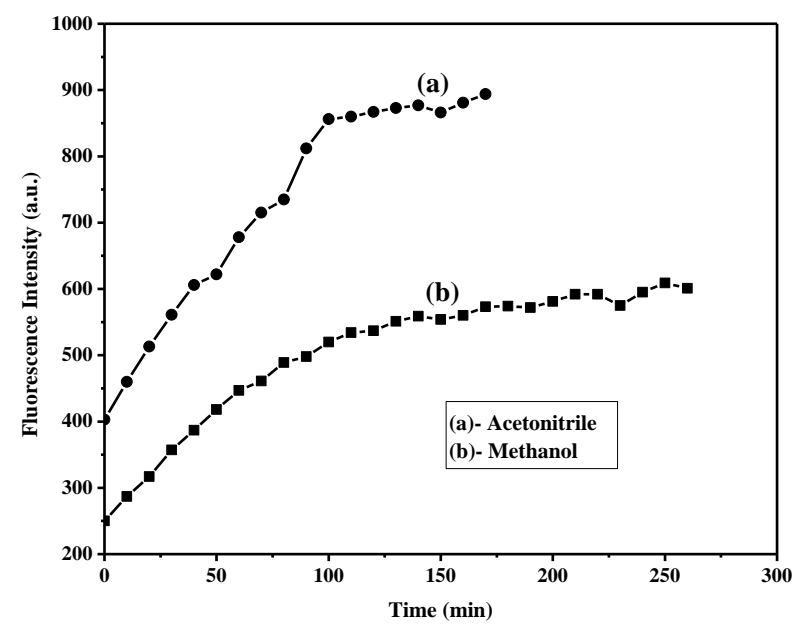

Fig. 1. Kinetic curves of benomyl $\left(10^{-6} \mathrm{M}\right)$ solvolysis in: (a) acetonitrile, (b) methanol

The initial increase observed for the $\mathrm{I}_{\mathrm{F}}$ value might be explained by the hypothesis that the most abundant metabolite (carbendazim) formed was probably more fluorescent than benomyl itself in these organic solutions [2]. Indeed, it is worthwhile noting that we independently recorded the excitation and emission spectra of both fungicides, and that we found that they were practically similar and quasi-completely overlapped. Since, in our study, the evolution of analytical fluorescence signal with time was measured at constant fluorescence excitation and emission maximum wavelengths $\left(\lambda_{\mathrm{ex}}=286 \mathrm{~nm} / \lambda_{\mathrm{em}}=306 \mathrm{~nm}\right)$, which corresponded 
to both fungicides, the observed $I_{\mathrm{F}}$ increase could be considered to be in agreement with the abovementioned hypothesis.

\subsubsection{Aqueous media}

For aqueous media, preliminary measurements showed that the benomyl solvolysis rate markedly varied with the $\mathrm{pH}$ value. Moreover, there was a significant difference in kinetic behaviour between the borate buffer and the sodium hydroxide aqueous solutions when these reagents were used to obtain the desired $\mathrm{pH}$ values.

\subsubsection{Effect of $\mathrm{NaOH}$ aqueous solution concentration}

In sodium hydroxide solutions, we observed that the benomyl solubility and stability increased with the $\mathrm{NaOH}$ concentration, whereas the fluorescence signal in the plateau region of kinetic curves decreased for increasing $\mathrm{NaOH}$ concentrations (Fig. 2).

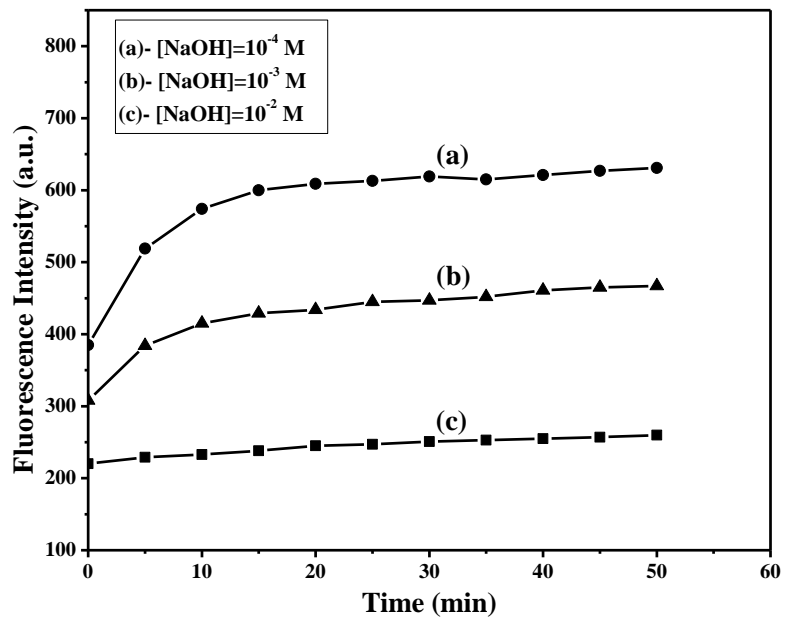

Fig. 2. Kinetic curves of benomyl $\left(10^{-6} \mathrm{M}\right)$ solvolysis in different $\mathrm{NaOH}$ aqueous solutions.

$\mathrm{NaOH}$ concentration = (a) $10^{-4} \mathrm{M}$; (b) $10^{-3} \mathrm{M}$; (c) $10^{-2} \mathrm{M}$

The kinetic curve obtained at a concentration of $10^{-2} \mathrm{M} \mathrm{NaOH}$ showed that the benomyl fluorescence signal only slightly varied with time until approximately $50 \mathrm{~min}$. In contrast, in more diluted $\mathrm{NaOH}$ solutions $\left(10^{-4} \mathrm{M}\right.$ and $\left.10^{-3} \mathrm{M}\right)$, the benomyl fluorescence intensity moderately increased with time, confirming that, as already mentioned, the major degradation product (carbendazim) was more fluorescent than benomyl itself. In addition, the fluorescence excitation and emission maximum wavelengths of benomyl $(242 \mathrm{~nm}$, $287 \mathrm{~nm} / 316 \mathrm{~nm}$ ) and of its main reaction product, carbendazim ( $248 \mathrm{~nm}, 290 \mathrm{~nm} / 323 \mathrm{~nm}$ ) were very close, and overlapped in most $\mathrm{NaOH}$ solutions. We can conclude from our results that benomyl seemed to be much more stable in an aqueous $10^{-2}$ $\mathrm{M} \mathrm{NaOH}$ solution than in the other, more diluted $\mathrm{NaOH}$ solutions, which suggested the notable role of the $\mathrm{OH}^{-}$ions for stabilising benomyl. Although the benomyl fluorescence signal was smaller in the former solution, this stronger alkaline solution could be used as a reference medium for further analytical studies.

\subsubsection{2. pH effect of borate buffer solutions}

Benomyl borate buffer aqueous solutions were directly prepared at $\mathrm{pH}$ values of 4,7 and 10 . The fluorescence signal of these solutions decreased progressively with time, the fastest rate being observed in the case of the $\mathrm{pH} 10$ solutions (Fig. 3). Moreover, this behaviour was different from that observed for $\mathrm{NaOH}$ aqueous solutions, in which, as mentioned above, the $\mathrm{OH}^{-}$ions appeared to play an important role in benomyl stabilisation.

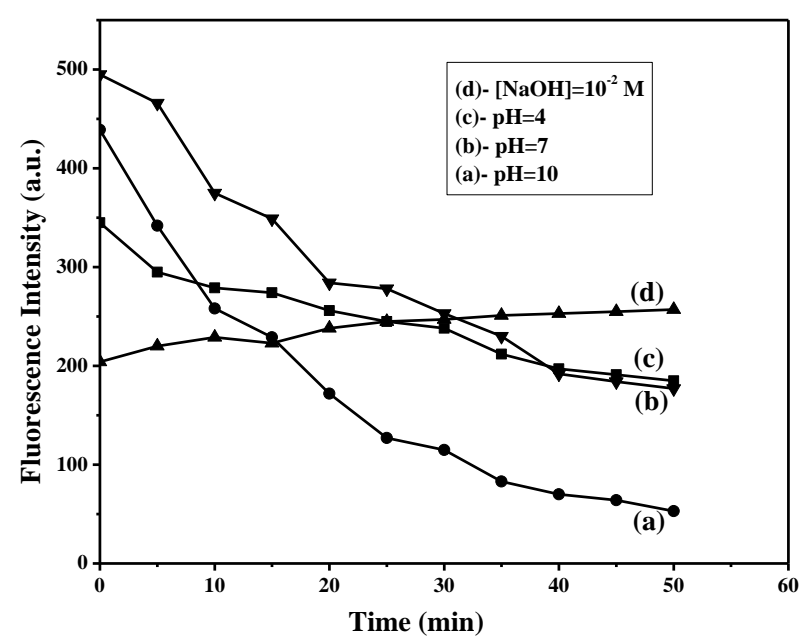

Fig. 3. Kinetic curves of benomyl $\left(10^{-6} \mathrm{M}\right)$ solvolysis in buffer borate aqueous solutions of different $\mathrm{pH}$. (a) $\mathrm{pH}=10$; (b) $\mathrm{pH}=7$; (c) $\mathrm{pH}=4$;

(d) in alkaline solutions of $[\mathrm{NaOH}]=10^{-2} \mathrm{M}$

\subsubsection{Effect of aqueous organized media}

The benomyl solvolysis kinetics were also investigated in several aqueous organised media, namely SDS, DTAC, CTAC, CTAOH, Brij-700, Triton X-100 and $\beta-C D$ solutions. In most organised media, the benomyl solvolysis kinetic curves were characterised by a more or less important apparent fluorescence intensity decrease with time, with the exception of $\mathrm{CTAOH}$ for which a fluorescence signal increase over time, followed by a plateau, was observed. Also, it is worthwhile not- 
ing that, in the case of Triton $\mathrm{X}-100$ solutions at various $\mathrm{pH}$ values and of $\beta$-CD neutral solutions, no significant fluorescence intensity variation with time was found. Indeed, in the latter two organised media, benomyl presented remarkable stability behaviour without any $\mathrm{pH}$ dependence. This feature can be related to the particular hydrophobic (or aggregational) properties and/or micropolarity of the Triton X-100 micelles and $\beta-C D$ core, which were significantly different to those of the SDS micelles core [20]. In these conditions, it is probable that the micropolarity of Triton X-100 micelles and of $\beta$-CD would allow benomyl, which possesses a notable polar region, to find a more satisfactory adsorption site in these organised media. Also, the difference in hydrophobic properties might permit a higher affinity of Triton X-100 micelles and $\beta-C D$ core to the weakly watersoluble fungicide benomyl molecules.

\subsubsection{Fluorescence properties, degradation times and stability of benomyl in different media}

In Table 1, the benomyl fluorescence excitation and emission maximum wavelengths, its optimal degradation (solvolysis) times $\left(t_{\mathrm{opt}}\right)$, corresponding to the time at which a fluorescence plateau region was reached, and/or its stability characteristics, in the different media and $\mathrm{pH}$ conditions under study are summarised.

The benomyl fluorescence spectra, recorded in methanol, acetonitrile, $10^{-4} \mathrm{M}$ and $10^{-2} \mathrm{M} \mathrm{NaOH}$ aqueous solutions, and in $\beta-\mathrm{CD}, \mathrm{CTAOH}, \mathrm{CTAC}$, DTAC, SDS, Brij-700 and Triton X-100 neutral and/or alkaline solutions $\left(10^{-2} \mathrm{M} \mathrm{NaOH}\right)$, presented similar features and shapes, with strong excitation and emission maximums, located in the 273-300 $\mathrm{nm}$ and in the 304-397 $\mathrm{nm}$ regions, respectively (Table 1 and Fig. 4).

Table 1

Medium effect on the benomyl fluorescence properties and solvolysis reaction kinetics

\begin{tabular}{|c|c|c|c|c|}
\hline Medium & $\mathrm{pH}$ conditions & $\lambda_{\mathrm{ex}} / \lambda_{\mathrm{em}}(\mathrm{nm})^{\mathrm{a}}$ & $t_{\text {opt }}(\min )^{\mathbf{b}}$ & $c_{0}(\mathrm{M})^{\mathrm{c}}$ \\
\hline Methanol & - & $286 / 306$ & 100 & $2 \times 10^{-6}$ \\
\hline Acetonitrile & - & $286 / 306$ & 100 & $2 \times 10^{-6}$ \\
\hline Water & {$[\mathrm{NaOH}]=10^{-4} \mathrm{M}$} & $287 / 316$ & 15 & $2 \times 10^{-5}$ \\
\hline Water & {$[\mathrm{NaOH}]=10^{-2} \mathrm{M}$} & $287 / 316$ & stable & $8 \times 10^{-6}$ \\
\hline$\beta-\mathrm{CD}$ & Neutral $^{\mathbf{d}}$ & $290 / 333$ & stable & $10^{-5}$ \\
\hline $\mathrm{CTAOH}$ & Neutral $^{\mathbf{d}}$ & $302 / 332$ & 30 & $2 \times 10^{-6}$ \\
\hline CTAC & Neutral $^{\mathbf{d}}$ & $293 / 397$ & non-stable & $2 \times 10^{-6}$ \\
\hline Brij-700 & Neutral $^{\mathbf{d}}$ & $293 / 390$ & non-stable & $6 \times 10^{-6}$ \\
\hline SDS & Neutral $^{\mathbf{d}}$ & $281 / 321$ & non-stable & $6 \times 10^{-6}$ \\
\hline DTAC & Neutral $^{\mathbf{d}}$ & $273 / 317$ & non-stable & $10^{-6}$ \\
\hline Triton X-100 & Neutral $^{\mathbf{d}}$ & $275 / 304$ & stable & $10^{-6}$ \\
\hline$\beta-C D$ & {$[\mathrm{NaOH}]=10^{-2} \mathrm{M}$} & $288 / 322$ & stable & $8 \times 10^{-6}$ \\
\hline CTAC & {$[\mathrm{NaOH}]=10^{-2} \mathrm{M}$} & $286 / 317$ & stable & $8 \times 10^{-6}$ \\
\hline Brij-700 & {$[\mathrm{NaOH}]=10^{-2} \mathrm{M}$} & $300 / 334$ & stable & $8 x \cdot 10^{-6}$ \\
\hline SDS & {$[\mathrm{NaOH}]=10^{-2} \mathrm{M}$} & $291 / 323$ & stable & $10^{-6}$ \\
\hline DTAC & {$[\mathrm{NaOH}]=10^{-2} \mathrm{M}$} & $273 / 317$ & stable & $10^{-6}$ \\
\hline Triton X-100 & {$[\mathrm{NaOH}]=10^{-2} \mathrm{M}$} & $275 / 304$ & stable & $10^{-6}$ \\
\hline
\end{tabular}

${ }^{\mathbf{a}} \lambda_{\mathrm{ex}}$ and $\lambda_{\mathrm{em}}=$ analytical excitation and emission maximum wavelengths (nm). ${ }^{\mathrm{b}} t_{\mathrm{opt}}=$ optimal degradation time (min), corresponding to the time at which a fluorescence plateau region was reached. ${ }^{\mathbf{c}} c_{0}=$ benomyl initial concentration (M). ${ }^{\mathbf{d}} \mathrm{Neutral}=\mathrm{pH} 7 \mathrm{medium}$ obtained by using equimolar concentrations $(0.01 \mathrm{M})$ of $\mathrm{NaOH}$ and $\mathrm{HCl}$.

The excitation maximum wavelengths were only moderately affected by the change in medium $\left(\Delta \lambda_{\mathrm{ex}}=-14-+19 \mathrm{~nm}\right)$ relative to methanol, according to the medium), whereas, for the emission maxima, more or less important shifts were observed in some media. For example, rather strong emission maximum wavelength red-shifts $\left(\Delta \lambda_{\mathrm{em}}=\right.$
$11-91 \mathrm{~nm})$ were found in neutral $\beta-C D$ and micellar media (CTAOH, CTAC, Brij-700, SDS) relative to methanol, with the exception of Triton X100 , for which the spectral shift was practically negligible $\left(\Delta \lambda_{\mathrm{em}}=-2 \mathrm{~nm}\right)$. Also, in the particular case of CTAC and Brij-700 media, important emission maximum wavelength blue-shifts $\left(\Delta \lambda_{\mathrm{em}}=\right.$ 
-56 to $-80 \mathrm{~nm}$ ) were observed, upon going from a neutral to a strongly alkaline organised medium $\left(10^{-2} \mathrm{M} \mathrm{NaOH}\right)$. In contrast, moderate emission maximum wavelength shifts generally occurred in strongly alkaline organized media, such as $\beta-\mathrm{CD}$, CTAC, DTAC, Triton $X-100$ and Brij-700, relative to $10^{-2} \mathrm{M} \mathrm{NaOH}\left(\Delta \lambda_{\mathrm{em}}=-12\right.$ to $\left.+18 \mathrm{~nm}\right)$. Moreover, a significant enhancement of the benomyl fluorescence signal was observed in aqueous micelle media and $\beta$-CD solutions, which appeared to be the most convenient media for analytical purposes. This behaviour was in agreement with data in the literature, which generally indicated an increase in the analyte solubility and fluorescence signal in these organised media [21-25].

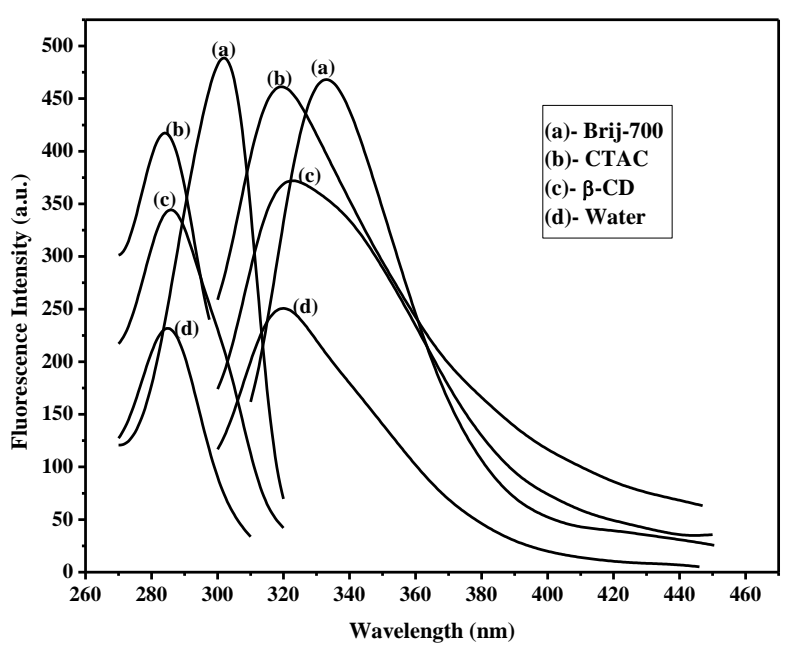

Fig. 4. Fluorescence excitation and emission spectra of benomyl $\left(10^{-6} \mathrm{M}\right)$ in $10^{-2} \mathrm{M} \mathrm{NaOH}$ solutions. (a) $0.006 \mathrm{M}$ Brij-700; (b) $0.006 \mathrm{M} \mathrm{CTAC;} \mathrm{(c)} 0.01 \mathrm{M} \beta$-CD; (d) water

In the case of kinetic curves with a plateau region, the $\mathrm{t}_{\mathrm{opt}}$ values in methanol, acetonitrile, $10^{-4}$ $\mathrm{M} \mathrm{NaOH}$ and neutral CTAOH solutions ranged between 15 and $100 \mathrm{~min}$, depending on the particular medium (Table 1).

In contrast, as already stated, benomyl was practically stable in $\beta-\mathrm{CD}$ neutral solution and Triton X-100 solutions of various $\mathrm{pH}$. Moreover, the fluorescence signal was practically constant in $10^{-2} \mathrm{M} \mathrm{NaOH}$ aqueous solution, as well as in $\beta$ CD, SDS, CTAC, DTAC, Brij-700 and Triton X100 alkaline solutions $\left(10^{-2} \mathrm{M} \mathrm{NaOH}\right)$, suggesting that benomyl was also stable in these media (Fig. 5). Therefore, the latter alkaline media seemed to be the most convenient for direct quantitative fluorescence analysis of benomyl, since the fluorescence signal was practically constant in these media.

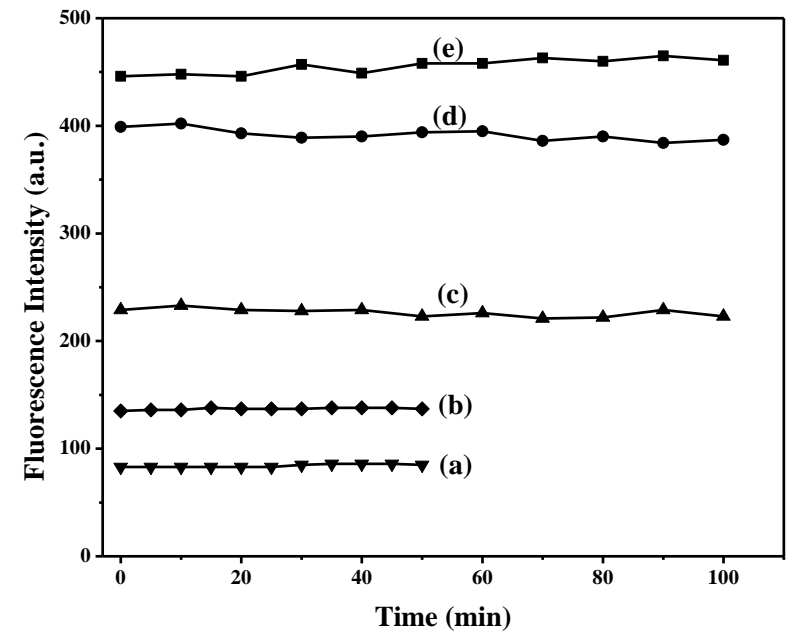

Fig. 5. Kinetic curves of benomyl $\left(10^{-6} \mathrm{M}\right)$ solvolysis in different $10^{-2} \mathrm{M} \mathrm{NaOH}$ aqueous organized media: (a) SDS (0.06 M); (b) DTAC (0.006 M); (c) $\beta-\mathrm{CD}(0.01 \mathrm{M})$; (d) CTAC (0.006 M); (e) Brij-700 (0.006 M)

\subsubsection{Kinetic laws and rate constants of benomyl solvolysis reactions}

In the case of aqueous solutions of various $\mathrm{pH}(\mathrm{pH}=4,7$ and 10), and of neutral and/or buffer, organised aqueous media, including DTAC, CTAC, SDS, Brij-700, for which the benomyl fluorescence signal apparently decreased with time, we used two distinct equations to treat the kinetic curves, in order to evaluate the solvolysis rate constant values. These equations were, respectively, for the first-order reactions:

$$
\ln \left(I_{\mathrm{F} 0} / I_{\mathrm{F}}\right)=k t
$$

and, for the second-order reactions:

$$
\left(I_{\mathrm{F} 0} / I_{\mathrm{F}}\right)=1+k[\mathrm{~B}]_{0} t
$$

in which: $I_{\mathrm{F} 0}$ and $I_{\mathrm{F}}=$ fluorescence intensity values at times $t=0$ and $t>0,[\mathrm{~B}]_{0}=$ benomyl initial concentration, and $k=$ solvolysis rate constant. For both equations, the goodness of the plot was judged by means of the correlation coefficient $\left(r^{2}\right)$ values. The kinetic equation (1) or (2) that gave the best fit (i.e. $r^{2}$ closer to unity) was considered the correct one, and the experimental $\mathrm{k}$ values were determined from the selected equation.

In Table 2, the benomyl solvolysis kinetic results obtained in aqueous solutions of different $\mathrm{pH}$, and in organised aqueous media, namely DTAC, CTAC, SDS, Brij-700 at different pH are presented.

As can be seen, the benomyl solvolysis reaction followed a first-order kinetic law in aqueous solutions, CTAC and DTAC, whereas a second- 
order law was observed in SDS and in Brij-700. The half-life time $\left(t_{1 / 2}\right)$ values strongly varied according to the medium, from $15 \mathrm{~min}$ in DTAC (pH4) to $117 \mathrm{~min}$ in SDS (pH7), which indicated that the benomyl degradation rate was relatively slow, and dependent on the type of medium. The benomyl solvolysis rate constant values ranged between about 0.01 and $0.10 \mathrm{~min}^{-1}$ for the $1^{\text {st }}$ order reactions, and between $8.5 \times 10^{2}$ and $3.6 \times 10^{4} 1 \mathrm{~mol}^{-1}$ $\min ^{-1}$ for the $2^{\text {nd }}$ order reactions, according to the medium used. Generally, most $k$ values were smaller in neutral $(\mathrm{pH} 7)$ aqueous solutions and organised media than at acidic or basic $\mathrm{pH}$.

T a b le 2

Kinetic parameters of the benomyl solvolysis reactions in different media

\begin{tabular}{|c|c|c|c|c|}
\hline Medium a,b & $\begin{array}{l}t_{1 / 2} \mathbf{c} \\
(\mathrm{min})\end{array}$ & $r^{2 \mathrm{~d}}$ & $\begin{array}{c}k \\
\left(\min ^{-1} \text { or } \mathrm{M}^{-1} \min ^{-1}\right)^{\mathrm{e}}\end{array}$ & Order $^{f}$ \\
\hline Water $(\mathrm{pH}=4)$ & 32 & 0.989 & $2.1( \pm 0.1) \times 10^{-2}$ & 1 \\
\hline Water $(\mathrm{pH}=7)$ & 63 & 0.990 & $1.1( \pm 0.05) \times 10^{-2}$ & 1 \\
\hline Water $(\mathrm{pH}=10)$ & 16 & 0.995 & $4.3 \pm(0.1) \times 10^{-2}$ & 1 \\
\hline CTAC (Neutral) & 72 & 0.987 & $9.7( \pm 0.7) \times 10^{-2}$ & 1 \\
\hline DTAC $(\mathrm{pH}=4)$ & 15 & 0.987 & $4.5( \pm 0.3) \times 10^{-2}$ & 1 \\
\hline DTAC $(\mathrm{pH}=7)$ & 22 & 0.985 & $3.2( \pm 0.3) \times 10^{-2}$ & 1 \\
\hline $\operatorname{SDS}(\mathrm{pH}=4)$ & 88 & 0,971 & $1.1( \pm 0.1) \times 10^{4}$ & 2 \\
\hline $\mathrm{SDS}(\mathrm{pH}=7)$ & 117 & 0.985 & $8.5( \pm 0.6) \times 10^{2}$ & 2 \\
\hline $\operatorname{SDS}(\mathrm{pH}=10)$ & 28 & 0.992 & $3.6( \pm 0.1) \times 10^{4}$ & 2 \\
\hline Brij-700 (Neutral) ${ }^{\mathrm{g}}$ & 56 & 0.997 & $4.5( \pm 0.2) \times 10^{3}$ & 2 \\
\hline
\end{tabular}

${ }^{\mathbf{a}} \mathrm{pH}=$ borate buffer solution $\mathrm{pH}$ values. ${ }^{\mathbf{b}} c_{0}=$ benomyl initial concentration $=10^{-6} \mathrm{M}$, except otherwise indicated.

${ }^{c} t_{1 / 2}=$ solvolysis reaction half-life time ( $\left.\mathrm{min}\right) .{ }^{\mathbf{d}} \mathrm{r}^{2}=$ kinetic equation correlation coefficient.

${ }^{\mathbf{e}} k=$ solvolysis rate constant $\left(\mathrm{min}^{-1}\right.$ or $\left.\mathrm{M}^{-1} \mathrm{~min}^{-1}\right)$ and absolute error $( \pm)$. ${ }^{\mathbf{f}}$ Order $=$ reaction kinetic order. ${ }^{\mathbf{g}} c_{0}=4 \times 10^{-6} \mathrm{M}$.

\subsubsection{Effect of the natural water sample type on the benomyl solvolysis reaction kinetics}

For application purposes, we also investigated the benomyl solvolysis kinetics in different natural water samples (sea, river, well, and draining waters) and in distilled and tap waters by fluorescence. Kinetic and physicochemical parameters are given in Table 3 for the benomyl solvolysis reaction in various water sample types.

T a b l e 3

Kinetic and physicochemical parameters of the benomyl $\left(c_{0}=10^{-6} \mathrm{M}\right)$ solvolysis reaction in different types of water samples and at various $\mathrm{pH}$ values

\begin{tabular}{lccccccc}
\hline \hline Type of water sample & $\begin{array}{c}\mathrm{NPOC} \\
(\mathrm{ng} / \mathrm{ml})\end{array}$ & $\begin{array}{c}\sigma \\
(\mathrm{mS} / \mathrm{cm})\end{array}$ & $\mathrm{pH}$ & $\begin{array}{c}t_{1 / 2}{ }^{\mathbf{c}} \\
(\mathrm{min})\end{array}$ & $r^{2 \mathbf{d}}$ & $\begin{array}{c}k \\
\left(\mathrm{~min}^{-1} \mathrm{or} \mathrm{M}^{-1} \mathrm{~min}^{-1}\right)^{\mathbf{e}}\end{array}$ & Order $^{\mathbf{f}}$ \\
\hline Distilled water & 0.15 & 0.001 & 7.01 & 131 & 0.994 & $5.3( \pm 0.2) \times 10^{-3}$ & 1 \\
Sea water & 3.56 & 42.90 & 9.32 & 291 & 0.982 & $2.4( \pm 0.2) \times 10^{-3}$ & 1 \\
River water & 1.43 & 0.069 & 6.89 & 295 & 0.995 & $2.3( \pm 0.1) \times 10^{-3}$ & 1 \\
Well water & 1.23 & 0.896 & 8.31 & 475 & 0.991 & $1.5( \pm 0.1) \times 10^{-3}$ & 1 \\
Tap water & 3.25 & 0.385 & 7.33 & 747 & 0.972 & $1.3( \pm 0.05) \times 10^{3}$ & 2 \\
Draining water & 2.95 & 0.091 & 6.71 & 1274 & 0.997 & $7.8( \pm 0.1) \times 10^{2}$ & 2 \\
\hline \hline
\end{tabular}

${ }^{\mathrm{a}} \mathrm{NPOC}(\mathrm{ng} / \mathrm{ml})=$ dissolved organic carbon, corresponding to the non-purgeable organic carbon present in natural waters. Calculated from the equation: NPOC $=$ TOC - POC, with NPOC $=$ non-purgeable organic carbon, TOC $=$ total organic carbon and POC $=$ purgeable organic carbon. ${ }^{\mathbf{b}} \sigma(\mathrm{mS} / \mathrm{cm})=$ water sample conductivity. ${ }^{\mathbf{c}} t_{1 / 2}=$ solvolysis reaction half-life time $(\mathrm{min}) .{ }^{\mathbf{d}} r^{2}=$ kinetic equation correlation coefficient.

${ }^{\mathbf{e}} k=$ solvolysis rate constant $\left(\mathrm{min}^{-1}\right.$ or $\left.\mathrm{M}^{-1} \mathrm{~min}^{-1}\right)$ and absolute error $( \pm)$. ${ }^{\mathbf{f}}$ Order $=$ reaction kinetic order.

The half-life time $\left(t_{1 / 2}\right)$ values markedly varied according to the type of water sample, from about $130 \mathrm{~min}$ for distilled water to about 1270 min for draining water, which indicated that the benomyl solvolysis rate was rather slow, and strongly dependent on the type of water sample.
Moreover, the solvolysis rate constants were determined by equations (1) or (2), as described above. The $k$ values obtained widely varied with the type of water sample, since they were between about 0.0015 and $0.0053 \mathrm{~min}^{-1}$ for the $1^{\text {st }}$ order reactions, and between about $7.8 \times 10^{2}$ and $1.3 \times 10^{3} 1$ 
$\mathrm{mol}^{-1} \mathrm{~min}^{-1}$ for the $2^{\text {nd }}$ order reactions (Table 3 ). The solvolysis reaction kinetic order was also dependent on the type of water sample. Indeed, the reaction was of the first-order in distilled water, sea, river and well waters, but of the second-order in tap and draining waters. However, there was apparently no correlation between the benomyl solvolysis rate constants and various water sample physicochemical parameters, such as the nonpurgeable total organic dissolved carbon (NPOC), $\mathrm{pH}$, and conductivity $(\sigma)$ (Table 3 ). This suggests that several combined physicochemical factors, varying significantly with the type of water sample, had an important and complex effect on the benomyl solvolysis rate constants. Moreover, benomyl appeared to be rather more stable in tap and draining waters, which would increase its persistence in both types of water samples. For the two later water sample types, because of the occurrence of second order solvolysis reactions, the benomyl persistence duration in aqueous environment would increase at lower initial benomyl concentrations.

\subsection{Benomyl determination by the direct spectrofluorimetric method}

\subsubsection{Analytical figures of merit}

In order to select the most interesting conditions from the analytical standpoint, we optimised our direct spectrofluorimetric method for benomyl determination by comparing the $I_{\mathrm{F}}$ values in the various media under investigation, in which a quasi-complete fluorescence signal stability was obtained. Relative to the benomyl fluorescence signal in $10^{-2} \mathrm{M} \mathrm{NaOH}$ aqueous solution, which was used as a reference medium, the highest $I_{F}$ values were found in Triton X-100 micellar medium under alkaline conditions $\left(10^{-2} \mathrm{M} \mathrm{NaOH}\right)$ and at $\mathrm{pH} 7$. Therefore, for comparison purposes, we decided to evaluate the analytical figures of merit of the fungicide in these three selected media, namely $10^{-2} \mathrm{M} \mathrm{NaOH}$ aqueous solution, Triton $\mathrm{X}-100$ at $\mathrm{pH} 7$ and in $10^{-2} \mathrm{M} \mathrm{NaOH}$ (Table 4).

\section{Table 4}

Spectrofluorimetric analytical figures of merit for the determination of benomyl

\begin{tabular}{lcccccc}
\hline \hline Medium & $\begin{array}{c}\text { LDR }^{\mathbf{a}} \\
(\mathrm{ng} / \mathrm{ml})\end{array}$ & Slope & $r^{2} \mathbf{c}$ & $\begin{array}{c}\text { LOD }^{\mathbf{d}} \\
(\mathrm{ng} / \mathrm{ml})\end{array}$ & $\begin{array}{c}\mathrm{LOQ}^{\mathrm{e}} \\
(\mathrm{ng} / \mathrm{ml})\end{array}$ & $\begin{array}{c}\mathrm{RSD}^{\mathrm{f}} \\
(\%)\end{array}$ \\
\hline Water $\left([\mathrm{NaOH}]=10^{-2} \mathrm{M}\right)$ & $14-8800$ & 0.89 & 0.997 & 0.5 & 2.0 & 1.7 \\
Triton-X-100 $(\mathrm{pH}=7)$ & $0.4-652$ & 0.99 & 0.999 & 0.04 & 0.14 & 0.5 \\
Triton-X-100 $\left([\mathrm{NaOH}]=10^{-2} \mathrm{M}\right)$ & $0.01-64$ & 0.98 & 0.999 & 0.002 & 0.007 & 0.2 \\
\hline \hline
\end{tabular}

${ }^{\mathbf{a}}$ LDR $=$ Linear dynamic range. ${ }^{\mathbf{b}}$ Slope $=$ slope of the calibration line. ${ }^{\mathbf{c}} r^{2}=$ Correlation coefficient. ${ }^{\mathbf{d}}$ LOD $=$ limit of detection, defined as the concentration of benomyl giving a signal-to-noise $(S / N)$ ratio of 3 (IUPAC criterion). ${ }^{\mathbf{e}} \mathrm{LOQ}=$ limit of quantification, defined as the concentration of benomyl giving a signal-to-noise $(S / N)$ ratio of 10 (IUPAC criterion). ${ }^{\mathrm{f}} \mathrm{RSD}=$ relative standard deviation $(n=3)$.

As can be seen in Table 4, linear calibration curves of fluorescence intensity vs. benomyl concentration were obtained over rather wide linear dynamic range (LDR) values of about two to three orders of magnitude, with $r^{2}$ values very close to unity, which indicated a good linearity of the analytical curves. As expected, the slopes of the log$\log$ plots were near unity. The reproducibility of measurements, evaluated with freshly-prepared benomyl solutions, was satisfactory, as indicated by the small relative standard deviation (RSD) values comprised between 0.2 and $1.7 \%$. The limit of detection (LOD) values were calculated on the basis of a benomyl concentration giving a signalto-noise ( $\mathrm{S} / \mathrm{N})$ ratio of 3 (IUPAC criterion). The LODs significantly varied with the medium, ranging from very low values of 0.002 and $0.04 \mathrm{ng} / \mathrm{ml}$ in Triton X-100 (respectively, in $10^{-2} \mathrm{M} \mathrm{NaOH}$ and $\mathrm{pH} 7$ solutions) to a higher value of $0.5 \mathrm{ng} / \mathrm{ml}$ in
$10^{-2} \mathrm{M} \mathrm{NaOH}$ aqueous solution. These differences meant that LOD values were about 12-250 times lower in Triton X-100 micellar medium than in classical, alkaline $\left(10^{-2} \mathrm{M} \mathrm{NaOH}\right)$ aqueous solution, which demonstrated the great analytical interest of utilising a micellar medium. The corresponding limit of quantification (LOQ) values, calculated for a signal-to-noise $(S / N)$ ratio of 10 , were comprised between $0.007 \mathrm{ng} / \mathrm{ml}$ in Triton X-100 $10^{-2} \mathrm{M} \mathrm{NaOH}$ and $2.0 \mathrm{ng} / \mathrm{ml}$ in $10^{-2} \mathrm{M} \mathrm{NaOH}$ aqueous solution (Table 4).

It is worthwhile emphasising that the best LOD and LOQ values, i.e. $0.002 \mathrm{ng} / \mathrm{ml}$ and 0.007 $\mathrm{ng} / \mathrm{ml}$, obtained for benomyl in Triton X-100 $10^{-2}$ $\mathrm{M} \mathrm{NaOH}$ by our direct fluorimetric method, were several orders of magnitude lower than those reported by authors using various indirect methods, based on the preliminary conversion of benomyl into carbendazim, such as fluorimetry (LOD $=12$ 
$\mathrm{ng} / \mathrm{ml}$ ) [2], the DLLME-LC method with fluorimetric detection (LOD $=3.3 \mathrm{ng} / \mathrm{ml}$ ) [10], and GCMS after derivatisation with $\mathrm{PFB}-\mathrm{Br} / \mathrm{K}_{2} \mathrm{CO}_{3}$ (LOD $=3 \mathrm{ng} / \mathrm{ml}$ ) [11]. Similarly, some direct spectrofluorimetric methods in the literature, in which the benomyl concentration was stabilised by several means before performing analysis, also led to significantly higher LOD and LOQ values than those reported in our study. For example, solid-phase spectrofluorimetry (SPF) gave a LOD of 0.04 $\mathrm{ng} / \mathrm{ml}$ [16], synchronous SPF yielded a LOD of $0.15 \mathrm{ng} / \mathrm{ml}$ [17], a spectrofluorimetric flow injection method led to a LOD of $3.6 \mathrm{ng} / \mathrm{ml}$ [18], and another spectrofluorimetric method provided a LOD of $17.4 \mathrm{ng} / \mathrm{ml}$ in hydroxypropyl- $\beta-C D$ [19]. Therefore, the very low LOD and LOQ values obtained in our work suggested that direct fluorescence in Triton X-100 media can be considered as a convenient and very sensitive method for determining benomyl residues in natural waters.

\subsubsection{Analytical applications to spiked water samples}

To verify the applicability of the proposed direct spectrofluorimetric method to authentic samples, benomyl was determined in spiked tap water, distilled water and natural water samples (sea water, river water, draining water and well water), after the above-described liquid-liquid extraction procedure. The water sample $\mathrm{pH}$ was adjusted to 12 by adding a $10^{-2} \mathrm{M} \mathrm{NaOH}$ solution before the extraction procedure. As shown in Table 5, we found satisfactory mean recovery values in the case of the various types of water samples under study, ranging from $87.5 \%$ to $94.1 \%$ for tap and distilled water, and from $88.9 \%$ to $93.8 \%$ for natural water samples, at different added benomyl concentrations. RSD values were rather small (1.4-3.9\%), which indicates a good reproducibility of the direct spectrofluorimetric method for analytical applications.

\title{
Table 5
}

\begin{abstract}
Analytical application of the direct spectrofluorimetric method to the determination of benomyl and evaluation of recovery values in spiked tap and distilled water and natural water samples
\end{abstract}

\begin{tabular}{|c|c|c|c|c|}
\hline Water sample & $\begin{array}{c}\text { Added benomyl } \\
\text { concentration }(\mathrm{ng} / \mathrm{ml})\end{array}$ & $\begin{array}{c}\text { Found benomyl } \\
\text { concentration }(\mathrm{ng} / \mathrm{ml})\end{array}$ & $\begin{array}{c}\text { Mean recovery }^{\mathrm{a}} \\
(\%)\end{array}$ & $\begin{array}{c}\operatorname{RSD}^{\mathrm{b}}(\%) \\
n=3\end{array}$ \\
\hline Tap water & 44.1 & $38.6 \pm 1.5$ & 87.5 & 3.9 \\
\hline Distilled water & 44.1 & $41.5 \pm 0.6$ & 94.1 & 1.4 \\
\hline Sea water & 44.1 & $40.8 \pm 1.5$ & 92.5 & 3.7 \\
\hline River water & 44.1 & $40.1 \pm 0.9$ & 90.9 & 2.2 \\
\hline Draining water & 56.7 & $50.4 \pm 1.6$ & 88.9 & 3.2 \\
\hline Well water & 56.7 & $53.2 \pm 0.8$ & 93.8 & 1.5 \\
\hline
\end{tabular}

${ }^{\mathrm{a}}$ Triplicate measurements for each benomyl concentration. ${ }^{\mathrm{b}} \mathrm{RSD}=$ relative standard deviation.

\section{CONCLUSION}

We can conclude from our work that benomyl is solvolysed in several organic and aqueous solutions, but practically not in neutral $\beta-\mathrm{CD}$ and Triton $\mathrm{X}-100$, in $10^{-2} \mathrm{M} \mathrm{NaOH}$ aqueous solution, and in organised media under alkaline conditions $\left(10^{-2} \mathrm{M} \mathrm{NaOH}\right)$. The comparative kinetic study of the benomyl solvolysis reaction in various media has led us to develop and optimise a very reliable, simple and sensitive spectrofluorimetric analytical method for the determination of benomyl in alkaline conditions, based on the direct fluorescence measurement of benomyl concentrations, without notable interference with the subsequent carbendazim formation. Indeed, although carbendazim is a compound that is relatively more stable than benomyl, its eventual presence in natural waters, possibly interfering with the benomyl fluorescence, should not result in any analytical problems because of the extraction procedure used in our spectrofluorimetric method prior to the effective analysis of natural waters. The main point of interest of this direct spectrofluorimetric method is that it can be easily applied to benomyl-treated fields, allowing the quantitative analysis of benomyl residues in an aqueous environment. Indeed, when spread in the environment, the fungicide is naturally solvolysed in aqueous medium. However, as shown by our kinetic study, solvolysis is not complete since the different benomyl degradation reactions reach a plateau region in most of the media investigated, which means that, under these conditions, equilibrium is achieved. In fact, immediately after collecting a natural water sample, it is recommended to add $10^{-2} \mathrm{M} \mathrm{NaOH}$ solution, in order to maintain a constant benomyl concentration in the water samples. We have obtained excellent ana- 
lytical results, which have enabled us to detect and quantify benomyl at very low concentrations, in the $\mathrm{ng} / \mathrm{L}$ range, with satisfactory recovery values in natural water samples. Another interesting feature of our method is that direct spectrofluorimetry is also very useful for monitoring the degree of decomposition of benomyl in organic and aqueous solutions. Therefore, we have acquired the knowhow required for realising the effective management of benomyl in aquatic systems.

Acknowledgements. One of the authors (D. D. Thiaré) would like to thank the Service of Cooperation and Cultural Action of the Embassy of France for financial support during his stay in the University of the Littoral Cote d'Opale at Dunkerque (France).

\section{REFERENCES}

[1] J. A. Itak, M. Y. Selisker, S. W. Jourdan, J. R. Fleeker, D. P. Herzog, Determination of benomyl (as carbendazim) and carbendazim in water, soil, and fruit juice by a magnetic particle-based immunoassay, J. Agric. Food Chem. 41, 2329-2332 (1993).

[2] F. Garcia-Sanchez, A. Aguilard-Gallardo, Fluorimetric determination of the fungicide benomyl after solvolysis. Microchim. Acta 116, 211-218 (1994).

[3] Y. C. Seo, K. D. Kim, N. J. Kim, Analysis of benomyl by liquid chromatography/time-of-flight mass spectrometry and its occurrence in the environment, Bull. Korean Chem. Soc. 23, 432-436 (2002).

[4] L. W. Hershberger, G. T. Arce, World Health Organization Geneva, 1993, International Programme on Chemical Safety (Benomyl EHC 148, 1993)

http://www.inchem.org/documents/ehc/ehc/ehc148.htm. (Accessed July 18, 2013)

[5] D. B. Armitage, US Department of Labor, OSHA Salt Lake Technical Center (1988), Benomyl Method PV2107: http://www.osha.gov/dts/sltc/methods/partial/tpv2107-01-8804-ch/t-pv2107-01-8804-ch.html. (Accessed July 18, 2013).

[6] R. J. Bushway, T. S. Fan, B. E. S. Young, L. R. Paradis, L. B. Perkins, Determination of methyl 2-benzimidazolecarbamate in soil by competitive inhibition enzyme immunoassay. J. Agric. Food Chem. 42, 1138-1142 (1994).

[7] R. Hassikou, K. Hassikou, A. O. Touhami, A. Badoc, A. Douira, Efficacité in vitro et in vivo de quelques fongicides sur curvularia lunata, Bull. Soc. Pharm. Bordeaux 142, 45-60 (2003).

[8] M. Assensio-Ramos, J. Hernandez-Borges, T. M. Borges-Miguel, M. A. Rodiguez-Degado, Ionic liquiddispersive liquid-liquid microextraction for the simultaneous determination of pesticides and metabolites in soils using high-performance liquid chromatography and fluorescence detection, J. Chromatogr. A 1218, 48084816 (2011).

[9] R. A. Levine, R. G. Luchtefeld, M. L. Hopper, G. D. Salmon, Automated method for clean up and determination of benomyl and thiabendazole in table-ready foods. J. AOAC Int. 81, 1217-1223 (1998).

[10] K. Farhadi, M. A. Farajzadeh, A. A. Matin, Liquid chromatographic determination of benomyl in water samples after dispersive liquid-liquid microextraction. $J$. Sep. Sci. 32, 2442-2447 (2009).

[11] M. Anastassiades, W. Schwack, Analysis of carbendazim, benomyl, thiophanate methyl and 2,4-dichlorophenoxyacetic acid in fruits and vegetables after supercritical fluid extraction. J. Chromatogr. A 825, 45-54 (1998).

[12] Y. Yamazaki, T. Ninomiya, Determination of benomyl, diphenyl, o-phenylphenol, thiabendazole, chlorpyrifos, methidathion, and methyl parathion in oranges by solidphase extraction, liquid chromatography and gas chromatography. J. AOAC Int. 82, 1474-1478 (1999).

[13] F. Garcia-Sanchez, A. Navas-Diaz, M. C. Torijas, Selective determination of carbaryl and benomyl by fluorescence polarization. Anal. Chim. Acta 414, 25-32 (2000).

[14] A. Navas-Diaz, F. Garcia-Sanchez, M. M. LopezGuerrero, Modulated anisotropy fluorescence for quantitative determination of carbaryl and benomyl. Talanta 60, 629-634 (2003).

[15] R. Halko, C. Padron-Sanz, Z. Sosa-Ferrera, J.-J. SantanaRodriguez, Determination of benzimidazole fungicides by HPLC with fluorescence detection after micellar extraction. Chromatographia 60, 151-156 (2004).

[16] J. L. Vilchez, L. F. Capitan-Vallvey, J. Rohand, A. Navalon, R. Avidad, Determination of benomyl residues in waters by solid-phase spectrofluorimetry. Analyst 120, 1609-1611 (1995).

[17] J. L. Vilchez, A. Navalon, J. Rohand, R. Avidad, L. F. Capitan-Vallvey, Simultaneous determination of benomyl and morestan residues in water by synchronous solidphase spectrofluorimetry. J. Fluoresc. 5, 225-229 (1995).

[18] J. F. Garcia-Reyes, P. Ortega-Barrales, A. Molina-Diaz, Development of a single fluorescence-based optosensor for rapid simultaneous determination of fungicides benomyl and thiabendazole in waters and commercial formulations. J. Agric. Food Chem. 52, 2197-2202 (2004).

[19] N. L. Pacioni, V. N. Sueldo-Occello, M. Lazzarotto, A. V. Veglia, Spectrofluorimetric determination of benzimidazolic pesticides: effect of p-sulfonatocalix[6]arene and cyclodextrins. Anal. Chim. Acta 624, 133-140 (2004).

[20] M. Shannigrahi, S. Bagchi, Novel fluorescent probe as aggregation predictor and micro- polarity reporter for micelles and mixed micelles. Spectrochim. Acta A 61, 2131-2138 (2005).

[21] R. P. Frankewich, K. N. Thimmaiah, W. L. Hinze, Evaluation of the relative effectiveness of different watersoluble $\beta$-cyclodextrin media to function as fluorescence enhancement agents. Anal. Chem. 63, 2924-2933 (1991).

[22] D. A. Lerner, M. A. Martin, Luminescence in organized media and supramolecular interactions: physicochemical aspects and applications. Analysis-European J. Anal. Chem. 28, 649-663 (2000).

[23] J.-J. Aaron, A. Coly, Photochemical-spectrofluorimetric determination of two pyrethroid insecticides using an anionic micellar medium, Analyst 121, 1545-1549 (1996).

[24] A. Coly, J.-J. Aaron, Cyclodextrin-enhanced fluorescence and photochemically-induced fluorescence determination of five aromatic pesticides in water. Anal. Chim. Acta 360, 129-141(1998).

[25] A. Coly, J.-J. Aaron, Photochemically-induced fluorescence determination of sulfonylurea herbicides using micellar media. Talanta 49, 107-117 (1999). 
